\title{
First record of Palombitrema triangulum (Suriano, 1981) Suriano, 1997 (Monogenea: Dactylogyridae) from freshwater fishes in Brazil
}

\author{
Abdallah, VD. ${ }^{a *}$, Azevedo, RK. $^{a}$ and Silva, RJ. ${ }^{b}$ \\ ${ }^{a}$ Universidade Sagrado Coração - USC, Rua Irmã Arminda, 10-50, Jardim Brasil, CEP 17011-160, Bauru, SP, Brazil

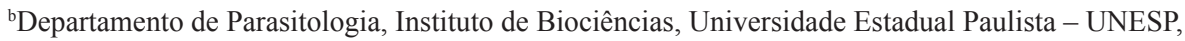 \\ Distrito de Rubião Junior, s/n, CEP 18618-970, Botucatu, SP, Brazil \\ *e-mail: vanessaabdallah@ig.com.br
}

Received: July 16, 2013 - Accepted: August 30, 2013 - Distributed: March 31, 2015

(With 2 figures)

\begin{abstract}
This study reports for the first time the monogenean Palombitrema triangulum Suriano (1981) in freshwater fishes from Brazil, highlighting new sites of infection for this helminth and some morphological differences. Monogeneans were collected on the body surface, gills and nasal cavity of two native fish species from Brazil, Cyphocharax modestus (Fernández-Yépez, 1948) and Cyphocharax nagelii (Steindachner, 1881). A brief morphological characterization of this species is presented.
\end{abstract}

Keywords: Palombitrema Triangulum, Cyphocharax modestus, Cyphocharax nagelii, Peixe's River, Brazil.

\section{Primeiro registro de Palombitrema triangulum (Suriano, 1981) Suriano, 1997 (Monogenea: Dactylogyridae) de peixes dulcícolas do Brasil}

\begin{abstract}
Resumo
Descreve-se a primeira ocorrência do monogenético Palombitrema triangulum Suriano (1981) em peixes dulcícolas do Brasil, destacando novos locais de infestação para este helminto e algumas diferenças morfológicas. Os monogenéticos foram coletados na superfície do corpo, brânquias e cavidade nasal de duas espécies de peixes nativos do Brasil, Cyphocharax modestus (Fernández-Yépez, 1948) e Cyphocharax nagelii (Steindachner, 1881). Uma breve caracterização morfológica desta espécie é apresentada.
\end{abstract}

Palavras-chave: Palombitrema triangulum, Cyphocharax modestus, Cyphocharax nagelii, rio do Peixe, Brasil.

\section{Introduction}

The monogenean Androspira triangula (Suriano, 1981) was described from gills of Pseudocurimata gilberti (=Cyphocharax gilbert) (Quoy and Gamard, 1824) in Laguna de Chascomús, Republica Argentina. Suriano (1997) considered Androspira (Suriano, 1981) a junior synonymy of Palombitrema Price and Bussing, 1968, and described the species Palombitrema triangulum. Currently, the genus Palombitrema includes three species: P. heteroancistrium Price and Bussing, 1968, P. chascomusense (Suriano, 1981) and $P$. triangulum reported in Argentina, Central America and southeastern Mexico (Mendoza-Franco et al., 2003).

Cyphocharax modestus (Fernández-Yépez, 1948) and Cyphocharax nagelii (Steindachner, 1881) are both benthopelagic and potamodromous species, zooplanktivorous (juveniles 40-50 days old) and detritivorous (larger individuals) distributed in South America: the first is found in upper Paraná River basin and Paraguay River above Sete Quedas Falls, and the other in upper Paraná River basin in Brazil (Froese and Pauly, 2011). The Peixe's River (4806’38'W; $22^{\circ} 49^{\prime} 53.1$ ' $\mathrm{S}$ ) is a tributary on the left bank of the middle Tiete River basin in Barra Bonita area, São Paulo State, Brazil, its headwaters are in the municipality of Torre de Pedra in the Basaltic Cuesta Botucatu Environmental Preservation Area and is a drainage basin corresponding to $584 \mathrm{~km}^{2}$ running North to South (Caramaschi, 1986).

Cyphocharax modestus and C. nagelii are common species in Peixe's river, and studies on the occurrence of monogeneans in fishes from this river have not been performed yet. The aim of this study was to report for the first time the occurrence of Palombitrema triangulum Suriano in freshwater fishes from Brazil, highlighting new sites of infection for this helminth.

\section{Material and Methods}

During a helminthological survey carried out between March and August 2010, 58 specimens of C. modestus and 56 specimens of $C$. nagelii were collected from the Peixe's River to study their monogeneans. Fish were collected 
using nylon monofilament gill nets with mesh sizes of $3-14 \mathrm{~cm}$ in three sites of Peixe's River. Nets were placed at $5 \mathrm{pm}$ and removed the next day at $7 \mathrm{am}$, thus exposed for $14 \mathrm{~h}$. The fish were removed from the nets and each specimen was separated in plastic bags. Some fish were maintained in coolers for one hour until necropsy, and others were frozen and analyzed posteriorly. The gills were removed and the gill arches were separated, placed in vials and filled with hot water $\left(60\right.$ to $\left.70^{\circ} \mathrm{C}\right)$. The vials were vigorously shaken to detach the parasites from the gill tissues. After 1 hour, absolute alcohol was added to the vials to fix the monogeneans. The body surface and nasal cavity were washed and sieved.

Some specimens were stained with Gomori's trichrome and mounted in Canada balsam, and others were mounted in Gray and Wess' medium (Humason, 1979) to study the sclerotized structures. Differential interference contrast microscopy (Leica DMLB 5000) was used for morphological examination. Measurements were obtained using a computerized image analysis system (LAS, Leica Microsystems, Wetzlar, Germany). Measurements (in micrometers) were expressed as mean followed by the range in parentheses. The illustrations were made with the aid of a camera lucida mounted on a Leica DMLS microscope. Voucher specimens were deposited in the Instituto Nacional de Pesquisas da Amazônia (INPA), Manaus, AM, Brazil and Coleção Helmintológica do Instituto de Biociências de Botucatu (CHIBB), Botucatu, SP, Brazil.

\section{Results}

\subsection{Morphological description (Figures 1 and 2)}

Based on twenty specimens: Dactylogyridae, Ancyrocetahlinae. Body fusiforme. Tegument smooth. Cephalic lobes incipient or absent, cephalic glands at level of pharynx. Eyes absent and accessory granules in cephalic
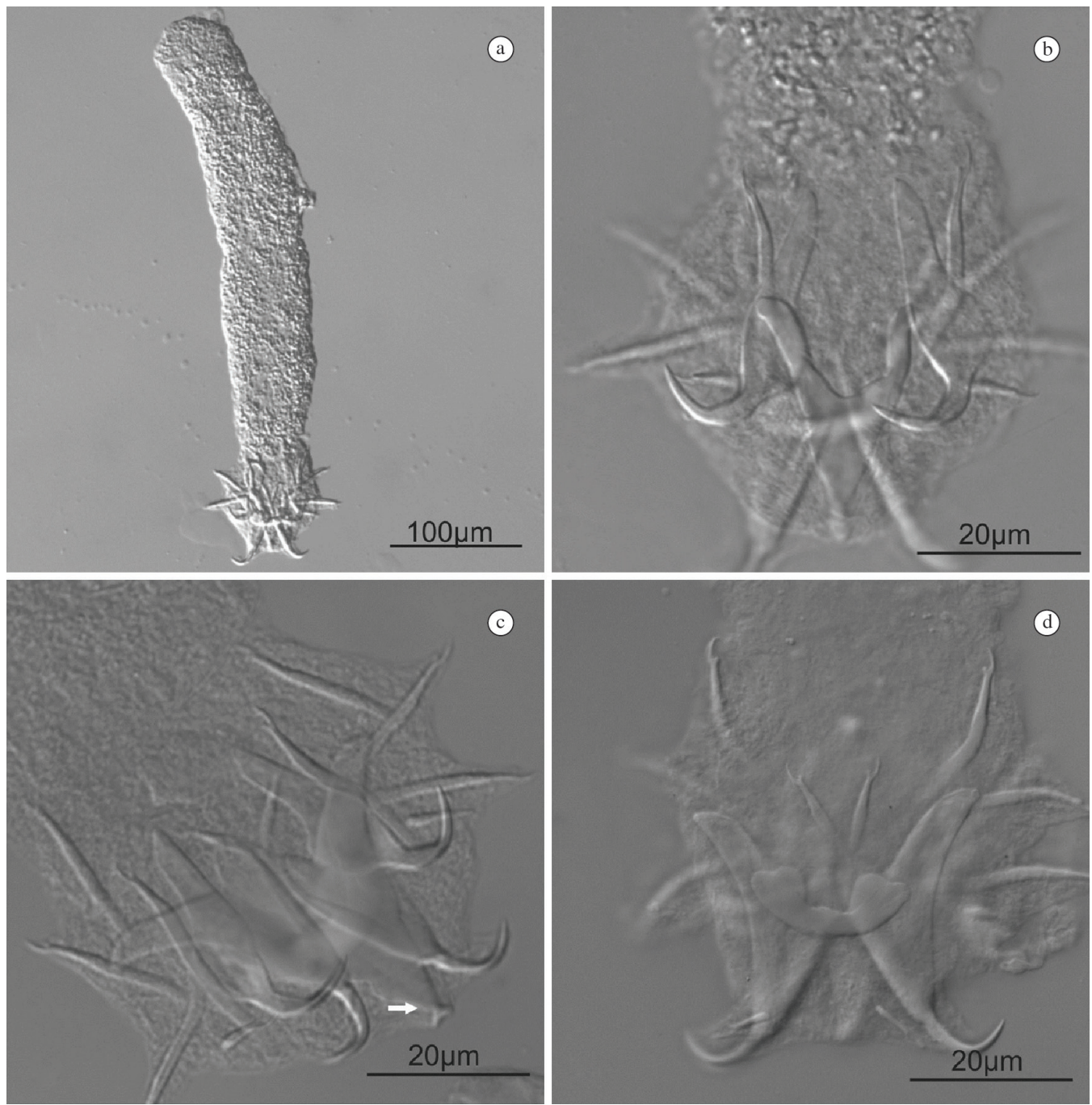

Figure 1. Palombitrema triangulum of Cyphocharax nagelii from Peixe's River, Brazil. (a) Whole worm, ventral view. (b) Haptor showing ventral anchor and bar. (c) Haptor showing hooks and detail of ventral anchor (arrow). (d) Haptor showing dorsal anchor and bar. 

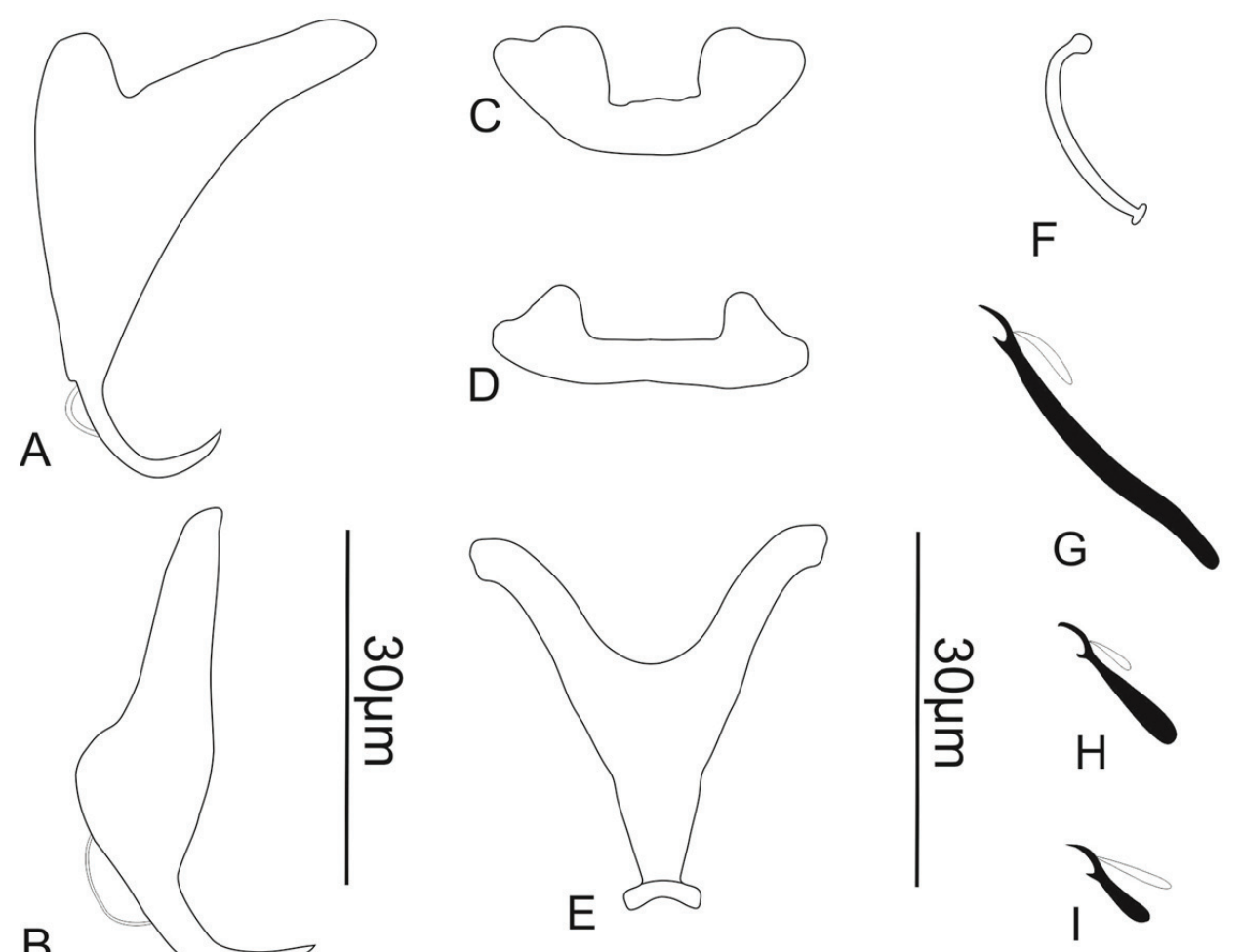

Figure 2. Palombitrema triangulum of Cyphocharax nagelii from Peixe's River, Brazil. (A) Dorsal anchor. (B) Ventral anchor. (C, D) Dorsal bars. (E) Ventral bar. (F) Vagina. (G) Hook Pairs 4-7. (H) Hook pairs 1 and 3. (I) Hook pair 2. Scale bar $30 \mu \mathrm{m}$.

area. Pharynx spherical. Peduncle short. Haptor subovate. Dorsal anchor with superficial root more developed than deep root, curved shaft and point. Ventral anchor with elongated superficial root and short deep root, curved shaft and point. Dorsal bar may present one of the two shapes: bowed with ends showing slight depression, or straight with rounded ends directed anteriorly. Ventral bar Y-shaped with a prominent projection. Hooks dissimilar. Ovary intercecal subovate; testis ovate postovarian. Cirrus tubular, spiral presenting three coils. Accessory piece composed by two pieces: one berry-shaped and other tweezers-shaped. One filament connects to the accessory piece with the base of cirrus. Seminal vesicle elongate; prostatic reservoir saccate. Vagina tubular dextral well sclerotized; seminal receptacle rounded. Vitellaria dense.

\subsection{Taxonomic summary}

Hosts: Cyphocharax modestus and Cyphocharax nagelii Locality: Peixe's River (4806’38'W; 22 49'53.1”S), Anhembi, SP, Brazil

Site of infection: Body surface, gills and nasal cavity Deposited specimens: INPA 597

\section{Discussion}

Morphometrical and morphological features of the studied specimens (Table 1) matches the description of P. triangulum by Suriano (1981). However, our specimens showed a ventral and dorsal anchor with superficial root more developed than the specimens described by the former authors and with filament present; in our specimens the dorsal bar can present two formats and the ventral bar present a prominent projection that is absent in specimens described by Suriano (1981). This may be related to intraspecies variations that are common in Monogenea or to an adaptive process (Kritsky et al., 1995). These same authors studied the morphometric variability of specimens of Scleroductus Jara and Cone, 1989 reported from the external surface of four Siluriformes from the Guandu River and questioned whether the observed variations in morphology and size are of specific value or result from influences of host and/or environmental factors.

Although there are evidences of monogeneans with a broad host species spectrum, most of them show high host specificity, occurring on a single species or on closely related fishes. The monogeneans of the family Dactylogyridae are usually found in the gills, but they can inhabit the nasal cavities and, in rare cases, other body parts of hosts (Zanolo and Yamamura, 2006). The species found in this study were described only in the gills of their host (Suriano, 1981), however we recorded it in other sites with high infestation prevalence, intensity and abundance (Table 2). This data represent important information about the biology of this parasite, increasing the knowledge of the monogenean host-parasite interaction. 
Table 1. Comparative measurements (in $\mu \mathrm{m}$ ) of Palombitrema triangulum from Pseudocurimata gilberti from Argentina (Suriano, 19981) and Cyphocharax modestus $(\mathrm{n}=58)$ and Cyphocharax nagelii $(\mathrm{n}=56)$ from the municipality of Anhembi, São Paulo State, Brazil.

\section{Laguna de Chascomus, Republica Peixe's River, municipality of Argentina (Suriano, 1981) Anhembi, São Paulo State, Brazil}

\begin{tabular}{lcc} 
& & (current study) \\
\hline Number of analyzed specimens & 50 & 20 \\
Ventral anchor a & $38(33-40)$ & $37(35-39)$ \\
Ventral anchor b & $23(20-30)$ & $20(18-23)$ \\
Ventral anchor c & 0 & 0 \\
Ventral anchor d & $16(15-20)$ & $19(17-21)$ \\
Ventral anchor e & $10(8-11)$ & $10(7-12)$ \\
Dorsal anchor a & $36(32-42)$ & $41(38-45)$ \\
Dorsal anchor b & $25(23-50)$ & $30(25-35)$ \\
Dorsal anchor c & $4(3-5)$ & $6(5-8)$ \\
Dorsal anchor d & $17(15-18)$ & $17(15-20)$ \\
Dorsal anchor e & $9(8-10)$ & $11(7-14)$ \\
Ventral bar x & $27(25-30)$ & $29(25-30)$ \\
Ventral bar w & $20(17-23)$ & $24(20-34)$ \\
Dorsal bar x & $22.5(20-25)$ & $23(21-27)$ \\
Dorsal bar w & $4(2.5-5)$ & $4(3-5.5)$ \\
Hook pairs I and III & $17(15-20)$ & $15(14-16)$ \\
Hook pair II & $9.5(8-10)$ & $10(7-13)$ \\
Hook pairs IV-VII & $28(25-30)$ & $29.5(24-33)$ \\
Accessory piece length & $37.5(35-40)$ & $30.9(26-33)$ \\
Cirrus length & $205(180-215)$ & $205(195-210)$ \\
Vagina & $40(35-50)$ & $19(14-21)$ \\
Body length & $270(245-280)$ & $297(243-433)$ \\
Body width & $50(45-60)$ & $47(33-65)$ \\
\hline
\end{tabular}

Table 2. Prevalence, mean intensity and mean abundance of Palombitrema triangulum in different sites of infestation from Cyphocharax modestus and Cyphocharax nagelii collected in Peixe's River, municipality of Anhembi, São Paulo State, Brazil.

\begin{tabular}{cccccc}
\hline Host & N & Prevalence $\mathbf{( \% )}$ & Mean intensity & $\begin{array}{c}\text { Mean } \\
\text { abundance }\end{array}$ & $\begin{array}{c}\text { Site of } \\
\text { infestation }\end{array}$ \\
\hline Cyphocharax modestus & 58 & 47 & $3.6 \pm 0.10$ & $2.9 \pm 0.07$ & Body surface \\
& & 73 & $6.8 \pm 0.30$ & $4.2 \pm 0.18$ & Gills \\
Cyphocharax nagelii & 35 & 72 & $4.7 \pm 0.11$ & $1.5 \pm 0.08$ & Nasal cavity \\
& & 67 & $5.9 \pm 0.14$ & $3.2 \pm 0.10$ & Body surface \\
& & 41 & $4.8 \pm 0.14$ & $3.3 \pm 0.15$ & Gills \\
& & & $1.9 \pm 0.10$ & Nasal cavity \\
\hline
\end{tabular}

This is the first record of $P$. triangulum in freshwater fishes from Brazil, and also the first report for the hosts C. modestus and C. nagelii.

\section{Acknowledgements}

Vanessa D. Abdallah was supported by a student fellowship from FAPESP (2009/51726-6), Rodney K. de Azevedo was supported by a student fellowship from FAPESP (2010/06564-5) and Reinaldo José da Silva was supported by a Research fellowship from CNPq (312590/2009-1) and FAPESP (2009/53316-0).

\section{References}

CARAMASCHI, EP., 1986. Distribuição da ictiofauna de riachos das Bacias do Tietê e do Paranapanema, junto ao divisor de águas (Botucatu, SP). São Carlos: Universidade Federal de São Carlos. 245 p. Tese de doutorado em Ecologia e Recursos Naturais.

FROESE, R. and PAULY, D., 2011. FishBase. Available from: $<\mathrm{http} / /$ www.fishbase.org $>$. Access in: 10 July 2011.

HUMASON, GL., 1979. Animal Tissue Techniques. San Francisco: W.H. Freeman Co. 661 p.

KRITSKY, DC., BOEGER, WA. and POPAZOGLO, F., 1995. Neotropical Monogenoidea. 22. Variation in Scleroductus species 
(Gyrodactylidae) from Siluriform fishes of Southeastern Brazil. Journal of the Helminthological Society of Washington, vol. 62 , p. 53-56.

MENDOZA-FRANCO, EF., POSEL, P. and DUMAILO, S., 2003. Monogeneans (Dactylogyridae: Ancyrocephalinae) of Freshwater Fishes from the Caribbean Coast of Nicaragua. Comparative Parasitology, vol. 70, no. 1, p. 32-41. http://dx.doi. org/10.1654/1525-2647(2003)070[0032:MDAOFF]2.0.CO;2.

SURIANO, DM., 1981. Androspira gen. no. (Monogenea Ancyrocephalinae) parasito branquial de Pseudocurimata gilberti (Quoy and Gaimard, 1824) Fernandez-Yepes, 1948 (Pisces
Tetragonopteridae) de La Laguna de Chascomus, Republica Argentina. Neotropica, vol. 27, p. 67-78.

SURIANO, DM., 1997. Palombitrema heteroancistrium Price and Bussing, 1968 (Monogenea: Ancyrocephalidae) from Astyanax (A.) fasciatus fasciatus (Cuvier, 1819) (Pisces: Characidae) in Chascomús Lake, Argentina: anatomy and systematic position. Physis (Buenos Aires) Section B, vol. 53, p. 7-10.

ZANOLO, R. and YAMAMURA, MH., 2006. Parasitas em tilápias-do-nilo criadas em sistemas de tanques-rede. Semina: Ciências Agrárias, vol. 27, no. 2, p. 281-288. 